\title{
Glyphosate-induced impact on the functional traits of the Bacillus sp. FC1 isolate ${ }^{1}$
}

\author{
Osiel Silva Gonçalves², Maria de Fátima Rodrigues da Silva ${ }^{2}$, Paula Fabiane Martins ${ }^{3}$
}

\section{ABSTRACT}

The intensive use of glyphosate has shown to be harmful to non-target organisms. Considering the soil as a final herbicide acceptor, the microbial community present on it is one of the critical factors to be monitored. This study aimed to isolate Bacillus sp., as well as to evaluate the effect of glyphosate on functional traits related to the growth and biocontrol activity of the phytopathogen. Bacillus sp. FC1 was isolated from the soil and grown in six media, in the presence and absence of glyphosate. The analysis of bacterial growth consisted of comparing the growth curves. The effect of glyphosate on the biocontrol activity was evaluated by antibiosis against the phytopathogen Fusarium sp. Glyphosate had a negative effect on the growth of the Bacillus sp. FC1 isolate. Exposure to the herbicide, based on the antibiosis method, showed no effect on the biocontrol activity of the phytopathogen. However, the sensitivity of the isolate to the herbicide may have affected its ability to initially compete for nutrients with the phytopathogen in the medium.

KEYWORDS: Biomonitoring, biocontrol, crop-beneficial soil bacteria, herbicide tolerance.

\section{INTRODUCTION}

Glyphosate [(N-phosphonomethyl) glycine] is one of the most widely used herbicides for weed control, which targets the enzyme 5-enolpyruvylshikimate-3-phosphate synthase (EPSPS) required for the synthesis of aromatic amino acids in the shikimate pathway (Gill et al. 2017). EPSPS is a precursor for the primary and secondary metabolisms of plants and many microorganisms; thus, its inhibition may affect the synthesis of a large number of secondary metabolites, including antifungal metabolites (Tzin \& Galili 2010). However, even though this herbicide may have a low contamination potential, its extensive use has

\begin{abstract}
RESUMO
Impacto induzido pelo glifosato nas características funcionais do isolado Bacillus sp. FC1

O uso intensivo de glifosato tem se mostrado prejudicial para organismos não-alvos. Considerando-se o solo como um dos receptores finais do herbicida, a comunidade microbiana presente é um dos fatores críticos a serem monitorados. Objetivou-se isolar Bacillus sp. e avaliar o efeito do glifosato nas características funcionais do crescimento e na atividade de biocontrole do fitopatógeno. Bacillus sp. FC1 foi isolado do solo e cultivado em seis tratamentos, na presença e ausência de glifosato. A análise de crescimento bacteriano consistiu na comparação das curvas de crescimento. $\mathrm{O}$ efeito do glifosato sobre a atividade de biocontrole foi avaliado por antibiose contra o fitopatógeno Fusarium sp. O glifosato apresentou efeito negativo no crescimento do Bacillus sp. FC1. A exposição ao herbicida, baseada no método de cultura pareada, não afetou a característica de biocontrole do fitopatógeno. Contudo, a sensibilidade do isolado ao glifosato pode ter afetado a capacidade inicial de competição por nutrientes com o fitopatógeno em placa.
\end{abstract}

PALAVRAS-CHAVE: Biomonitoramento, biocontrole, bactérias benéficas do solo, tolerância a herbicidas.

shown to be harmful to non-target organisms (Brito et al. 2017).

Studies have shown the effects of glyphosate on the soil microbial community (Newman et al. 2016, Van Bruggen et al. 2018), whose knowledge is important to understand how the shifts on ecological and functional traits of such communities, when under herbicidal effects, could lead to the loss of valuable ecosystem services (Newman et al. 2016). Therefore, Van Bruggen \& Semenov (2000) suggest a biomonitoring approach to the soil health by measuring bacteria responses to various stresses.

In the present study, Bacillus sp. rhizobacteria were used as a biological parameter. Bacillus sp. is a diverse and common soil bacterial species, ubiquitous

1. Received: Mar. 30, 2019. Accepted: Oct. 15, 2019. Published: Mar. 25, 2020. DOI: 10.1590/1983-40632020v5057954.

2. Universidade de Rio Verde, Rio Verde, GO, Brasil.E-mail/ORCID: osiel.goncalves@ufv.br/0000-0002-6311-799X, fatimars@hotmail.com/0000-0002-9100-639X.

3. Instituto Federal Goiano, Rio Verde, GO, Brasil.E-mail/ORCID: paula.martins@ifgoiano.edu.br/0000-0002-7850-3260. 
and broadly adapted to grow in diverse environments. It can be isolated in greater numbers from a variety of rhizospheres (Earl et al. 2008). In addition, Bacillus sp. is one the most related crop-beneficial soil bacterial genera and plays an essential role in several ecological processes, such as promoting growth and inducing systemic resistance in plants, and as a biocontrol agent by producing a broad range of antimicrobial compounds (Shafi et al. 2017, Lopes et al. 2018).

Although studies on the interaction between herbicides and soil microorganisms seek to understand biodegradation processes, the impact of herbicides on their functional traits has been poorly documented. Therefore, the present study aimed to isolate Bacillus from the soil and evaluate the effect of glyphosate on functional traits related to growth and phytopathogen biocontrol activity.

\section{MATERIAL AND METHODS}

The experiment was carried out at the Instituto Federal Goiano, in Rio Verde (Goiás state, Brazil), from August to December 2016.

Soil samples were obtained from the rhizosphere of carvoeiro (Tachigali vulgaris), a native Brazilian Savannah tree, collected at the Universidade de Rio Verde, in Rio Verde, Goiás state, Brazil (17\%46'59.2"S and 50 ${ }^{\circ} 57^{\prime} 59.5^{\prime}$ 'W). About $10 \mathrm{~g}$ of soil of each sample were homogenized in $90 \mathrm{~mL}$ of peptone water $\left(\mathrm{H}_{2} \mathrm{Op}\right)$ and treated in a water bath at $80{ }^{\circ} \mathrm{C}$, for $12 \mathrm{~min}$. Serial dilution in $\mathrm{H}_{2} \mathrm{Op}$ was performed at a concentration of $10^{-1}$, $10^{-2}$ and $10^{-3}$ bacteria and inoculated $(100 \mu \mathrm{L})$ in nutrient agar. The selected isolates were put aside for further morphological and biochemical studies (Buchanan \& Gibbons 1975). Bacterial DNA extraction was performed using the DNeasy ${ }^{\mathbb{R}}$ Blood \& Tissue Kit (QIAGEN, Hilden, Germany), according to the manufacturer's instructions. In addition, a partial sequence of the 16S rRNA gene was amplified with primers R1387 (5'- CGG TGT GTA CAA GGC CCG GGA ACG - 3') (Heuer et al. 1997) and P027F (5' - GAG AGT TTG ATC CTG GCT -3') (Lane et al. 1985). Sequencing analysis was conducted using an ABI 3130 Genetic Analyzer (Applied Biosystems), aligned by ClustalW in Mega 7 (Kumar et al. 2016), and then the aligned sequence was used for the construction of a phylogenetic tree based on maximum parsimony.
The Universidade de Rio Verde provided potassium salt of glyphosate - under the trade name Roundup Transorb $\mathrm{R}^{\circledR}$ (containing $480 \mathrm{~g} \mathrm{~L}^{-1}$ of the active ingredient of glyphosate). Minimal medium (MM) was defined as the basal medium for the experiment. The medium, in $\mathrm{g} \mathrm{L}^{-1}$ of distilled water and $\mathrm{pH}$ (7.0), was composed of $\mathrm{KH}_{2} \mathrm{PO}_{4}$ (1.5), $\mathrm{Na}_{2} \mathrm{HPO}_{4}(0.6), \mathrm{NaCl}(0.5), \mathrm{NH}_{4} \mathrm{SO}_{4}(2), \mathrm{MgSO}_{4}$ $7 \mathrm{H}_{2} \mathrm{O}(0.2), \mathrm{CaCl}_{2}(0.01)$ and $\mathrm{FeSO}_{4} 7 \mathrm{H}_{2} \mathrm{O}(0.001)$ (Dworkin \& Foster 1958). Nutrient broth (NB) was also used, being composed, in $\mathrm{g} \mathrm{L}^{-1}$, of peptone (10), beef extract (10) and $\mathrm{NaCl}(5)$. The media with the herbicide were supplemented with $7.2 \mathrm{mg} \mathrm{mL}^{-1}$ of glyphosate. The dextrose concentration in the minimal medium dextrose (MMD) and minimal medium dextrose herbicide (MMDH) treatments was $1 \%(\mathrm{w} / \mathrm{v})$.

The isolated strains were grown aerobically in $\mathrm{NB}$ at $27^{\circ} \mathrm{C}$, for $36 \mathrm{~h}$. The bacterial culture was standardized to $1 \%$ of the original $(\lambda=0.8$ at $600 \mathrm{~nm})$. The selected strain was grown in $250 \mathrm{~mL}$ Erlenmeyer flasks containing $50 \mathrm{~mL}$ of six media in the presence and absence of glyphosate and incubated in the dark on a rotary shaker $(100 \mathrm{rpm})$ at $27^{\circ} \mathrm{C}$, for $168 \mathrm{~h}$. The bacterial growth was monitored by measuring the optical density (OD) in a spectrophotometer, at a wavelength of $600 \mathrm{~nm}$, while the cell viability was measured by colony-forming unit (CFU). After $15 \mathrm{~h}$ of exposure to the treatments, the samples $(100 \mu \mathrm{L})$ were diluted in a physiological solution containing $0.85 \% \mathrm{NaCl}$ and loaded in triplicate onto nutrient agar plates incubated at $30^{\circ} \mathrm{C}$, for $24 \mathrm{~h}$. The data expressed in CFU mL $\mathrm{m}^{-1}$ were converted to $\log \mathrm{CFU} \mathrm{mL} \mathrm{m}^{-1}$.

For the antibiosis assay after the exposure to glyphosate, the selected isolated strain was grown in 4-L Erlenmeyer flasks containing 1.3 L of nutrient broth and incubated in the dark on a rotary shaker $(150 \mathrm{rpm})$ at $27^{\circ} \mathrm{C}$. The cell extraction was performed during the exponential phase. The culture was centrifuged at 5,000 rpm, for $5 \mathrm{~min}$. The pellets were homogenized in a physiological solution of $0.85 \%$ $\mathrm{NaCl}$ and separated into aliquots for the following treatments: MMD, MMDH, NB and NBH (NB supplemented with herbicide). After $15 \mathrm{~h}$ of exposure to the treatments, the cultures were centrifuged at $5,000 \mathrm{rpm}$, for $5 \mathrm{~min}$, and subsequently washed. The cells obtained from each treatment were suspended in a physiological solution and transferred to sterile Petri dishes. A sterilized potato dextrose agar (PDA) medium was cooled to $40 \sim 50{ }^{\circ} \mathrm{C}$, cell suspension was 
added, rapidly shaken, and poured into a Petri dish (Pour plate). After the medium solidification, 5-mm diameter mycelial discs of Fusarium sp. were placed on the center of the PDA plate and then incubated at $25^{\circ} \mathrm{C}$ in the dark. The antibiosis dishes (Bacillus sp. $\mathrm{FC} 1$ after exposure to treatments and to Fusarium sp.) and the control dish (Fusarium sp. growing without Bacillus sp. FC1) were incubated for two weeks and then the mycelial growth of the phytopathogens was evaluated.

The percentage of growth inhibition was calculated using the formula (R1-R2)/R1 x 100, where $\mathrm{R} 1$ is the radial distance of the Fusarium sp. mycelium in the absence of the antagonist from the center to the edge of the plate (measured in $\mathrm{mm}$ ) and $\mathrm{R} 2$ is the growth distance of Fusarium sp. from the center of the plate to the bank toward Bacillus sp. FC1. Each treatment was repeated three times. All experiments had a completely randomized design and were conducted in three replicates for each treatment. The significance of the observed differences was verified using one-way analysis of variance (Anova) followed by the Tukey test. All statistical analyses were performed using the R Studio software (R Core Team 2017).

\section{RESULTS AND DISCUSSION}

Several morphologically different colonies were isolated and purified. Based on the morphological, structural and biochemical characterizations, the FC1 isolate exhibited similarity to the Bacillus genus.
The isolate also produced amylase, catalase, acetyl methyl carbinol (acetoin) from glucose fermentation, citrate utilization, tolerance to high temperature, and salinity (Table 1).

By 16S rRNA partial gene sequencing (905 bp), the isolate displayed similarity (96\%) with Bacillus sp. A phylogenetic tree was generated using Bacillus strains closely related to the $\mathrm{FC} 1$ isolate by comparison of the 16S rRNA sequence to the National Center for Biotechnology Information (NCBI) database. The FC1 isolate is related, clustered, with Bacillus sp. (KR259192.1) (Figure 1). Based on the results of the biochemical tests, $16 \mathrm{~S}$ rRNA partial gene sequence and the phylogenetic tree, it was concluded that the FC1 belonged to a Bacillus species.

Table 1. Morphological, structural and biochemical tests conducted for the Bacillus sp. FC1 isolate identification.

\begin{tabular}{lc}
\hline \multicolumn{1}{c}{ Tests } & Results \\
\hline Morphology & Rod shape \\
Gram staining & + \\
Sporulation & + \\
Starch hydrolysis & + \\
Voges Proskauer & + \\
Methyl red & - \\
Citrate utilization & + \\
Growth in $6.5 \% \mathrm{NaCl}$ & + \\
Growth at $50^{\circ} \mathrm{C}$ & + \\
Catalase & + \\
\hline
\end{tabular}

(+) positive; (-) negative.

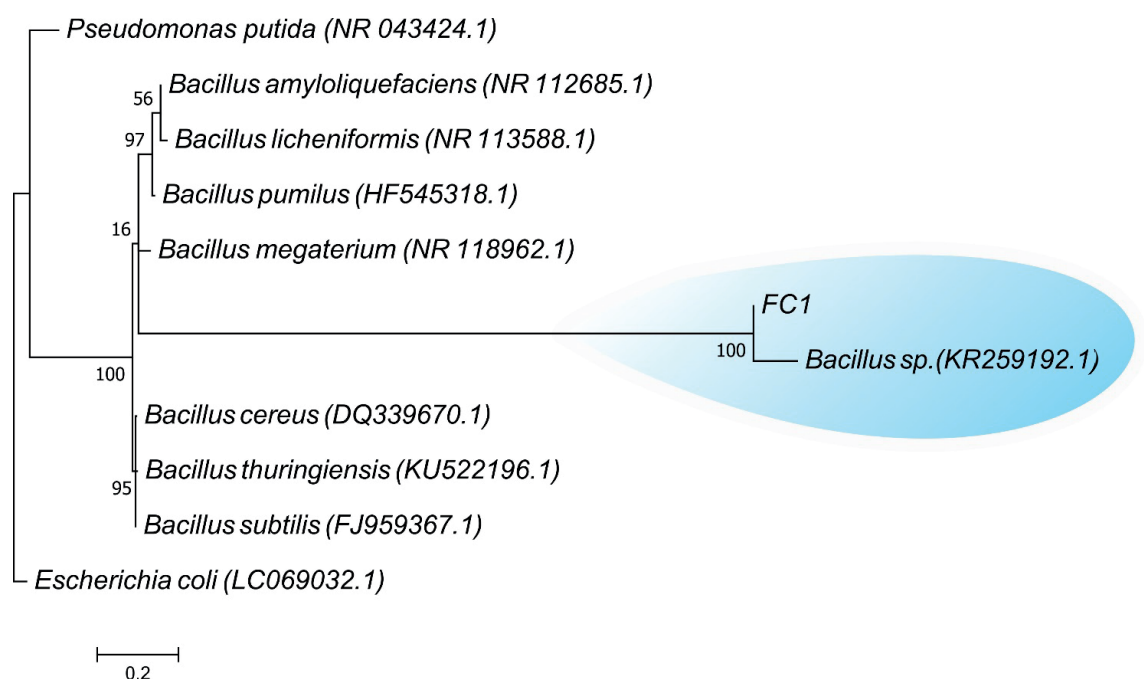

Figure 1. Maximum-parsimony phylogenetic tree constructed from the 16S rRNA sequence of the Bacillus sp. FC1 isolate and related sequences obtained from the National Center for Biotechnology Information (NCBI) database. The GenBank accession number for each strain is shown in parentheses. Escherichia coli (LC069032.1) was used as an outgroup. 
Previously, a screening curve was determined to analyze the bacterial behavior at first exposure to glyphosate (Figure 2). The Bacillus sp. FC1 growth was dramatically affected in the presence of glyphosate, with the highest growth level being $0.060 \mathrm{~nm}$, for $168 \mathrm{~h}$ of incubation. Differential growth in response to medium constitutions revealed significant differences $(\mathrm{p}<0.05)$ between the treatments.

With the screening curve, it was possible to determine the glyphosate effect on the growth of the Bacillus sp. FC1. However, the screening curve only showed the OD averages in the decline phase, which occurred between $24 \mathrm{~h}$ and $48 \mathrm{~h}$ - visible on the MMD graph bars (Figure 1). Furthermore, the minimal medium represents a simple medium without any alternative carbon source, except for MMD and $\mathrm{MMDH}$, which does not provide sufficient energy to allow for cellular propagation (Martins et al. 2011). Additionally, auxiliary carbons increase the biodegradation potential of the bacterial culture by increasing its metabolic activity (Kumar \& Philip 2006). In view of that, a complex medium (NB, nutrient broth) was added so as to investigate whether such a low growth was due to the medium composition.

Glyphosate also affected the growth of the Bacillus sp. FC1, when cultured in the media containing a complex carbon source (NBH). As shown in Figure 3, the highest growth level was observed in

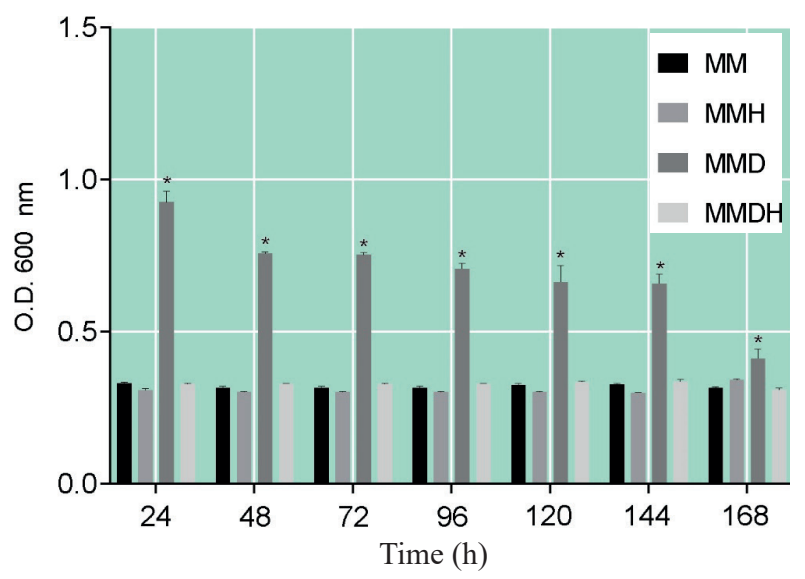

Figure 2. Screening curve of the Bacillus sp. FC1 in the absence (control) and presence of glyphosate, for $168 \mathrm{~h}$ of incubation. The results represent the means obtained with data from the replicates $(n=3)$. Means are significantly different $(p<0.05)$ by the analysis of one-way variance (Anova) and the Tukey test. MM: minimal medium; MMH: minimal medium herbicide; MMD: minimal medium dextrose; MMDH: minimal medium dextrose herbicide. the control media (NB and MMD). Glucose is often used as a carbon source for bacteria, in order to enhance their growth and metabolism, present in dextrose, MMD and MMDH. However, the Bacillus sp. FC1 was unable to use it as a sole carbon source in the presence of glyphosate. This result could be attributed to the inhibition of the enzyme EPSPS, essential in the shikimate pathway, responsible for the biosynthesis of aromatic amino acids in plants and microorganisms (Schulz et al. 2006). Aristilde et al. (2017) showed that aromatic amino acid supplementation in the growth medium leads to the recovery of metabolic homeostasis in soil Pseudomonas species, when cultured with herbicide. Their finding supports the inhibition of aromatic amino acids by the EPSPS interruption in the shikimate pathway.

The cell viability data showed a strong concordance with growth kinetics (Figure 3), as shown in Figure 4. After exposed to glyphosate for $15 \mathrm{~h}$, though relatively low in the treatments with herbicide, an increase in the number of viable cells was observed, if compared to the concentration of the initial inoculum (Figure 4). This result suggests that glyphosate has a bacteriostatic effect on the Bacillus sp. FC1 growth (i.e., temporarily inhibits the bacterium growth). The low metabolic rate on the MMDH and NBH treatments can be a mechanism to protect the cell against the toxic effects of the herbicide (Gray et al. 2019), resulting in an herbicide tolerance mechanism. Martins et al. (2011) also reported the effects of herbicides on soil bacteria and showed the activation of antioxidant enzymes as the herbicide tolerance mechanism.

The Bacillus sp. FC1 was $95 \%$ effective in the growth inhibition of Fusarium sp., which did not differ between treatments in the presence and absence of glyphosate (data not shown). However, a clear zone surrounding the mycelia of the Fusarium sp. and FC1 was detected in both culture media treatments (Figure 5).

It was investigated whether the mycelial growth produced a larger halo on the Bacillus sp. FC1 lawn in the glyphosate treatments (NBH and $\mathrm{MMDH})$ than that in the control treatment (NB and MMD). However, in terms of occurrence, both treatments varied in clearer and well-defined halos during the incubation (Table 2).

After two weeks of incubation, it was observed a late mycelial growth of Fusarium sp., which overlapped the halos in the MMDH and NBH 
A

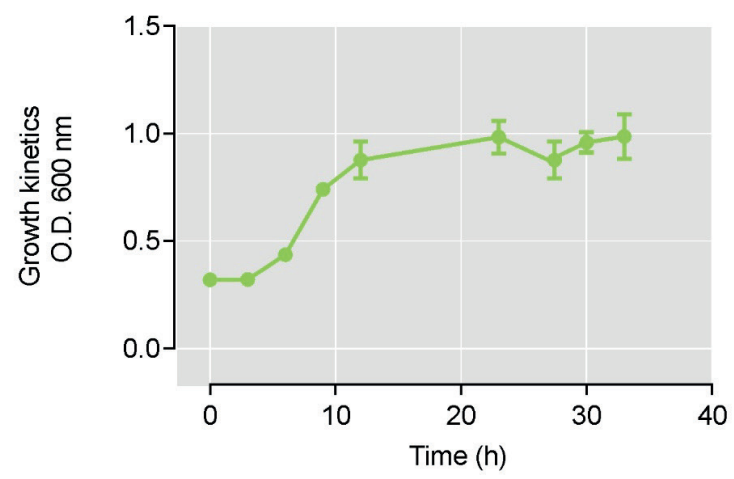

C

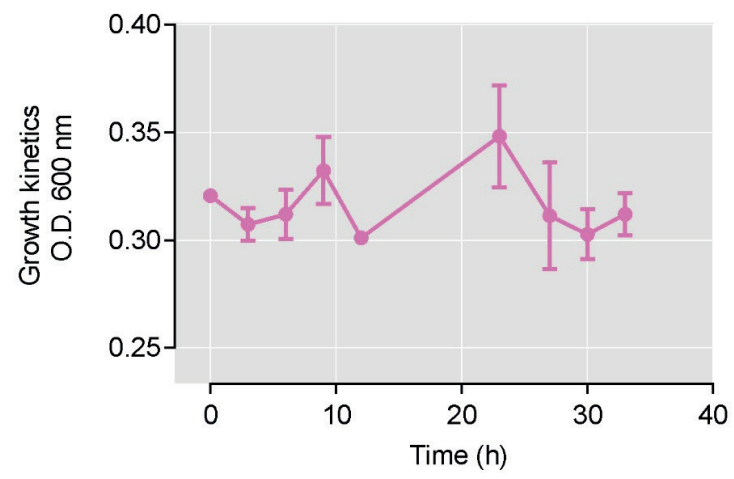

B

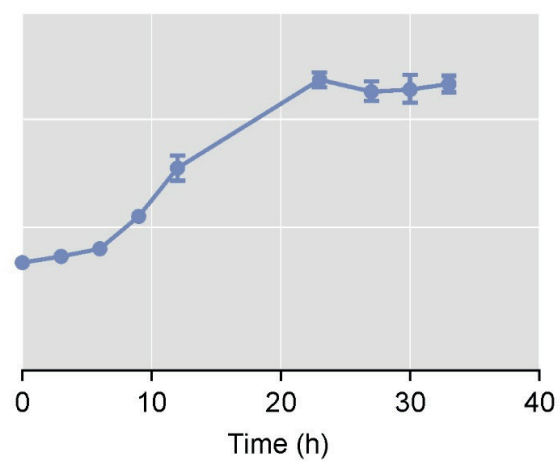

D

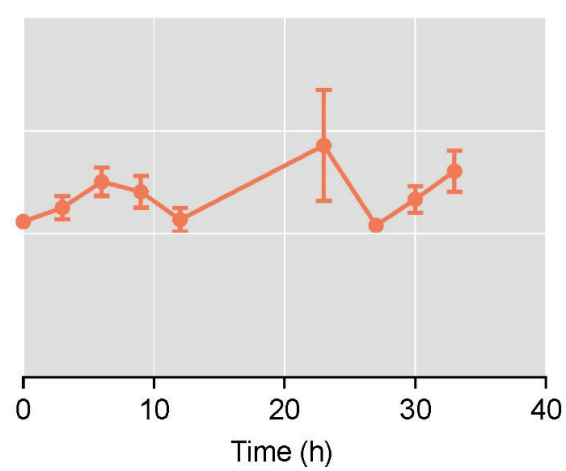

Figure 3. Growth kinetics of the Bacillus sp. FC1 in the absence and presence of glyphosate, for $33 \mathrm{~h}$ of incubation. A) nutrient broth; B) minimal medium dextrose; C) nutrient broth herbicide; D) minimal medium dextrose herbicide. Results represent the means obtained with data from the replicates $(n=3)$.

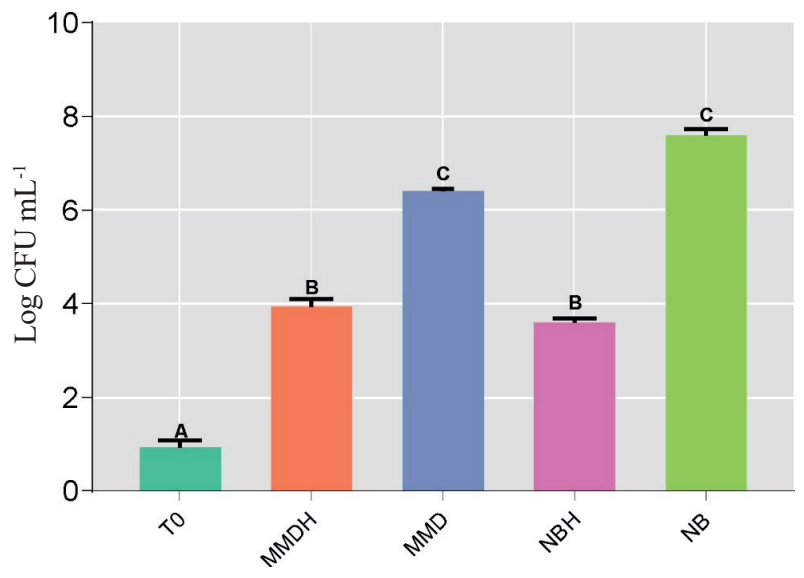

Figure 4. Cell viability after exposure to glyphosate for $15 \mathrm{~h}$, measured by colony-forming unit $\left(\log \mathrm{CFU} \mathrm{mL}^{-1}\right)$. The values represent the means from three experiments \pm SEM. Means with different letters are significantly different $(p<0.05)$ by one-way analysis of variance (Anova) and the Tukey test. T0: initial inoculum; NB: nutrient broth; NBH: nutrient broth herbicide; MMD: minimal medium dextrose; MMDH: minimal medium dextrose herbicide.

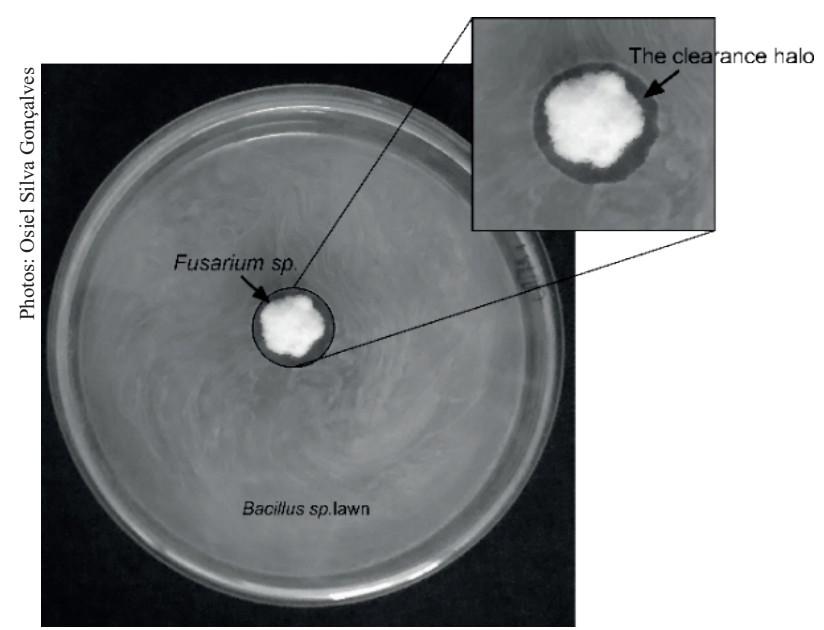

Figure 5. Co-culture interspecific interaction showing the clear zone surrounding the mycelia of Fusarium sp. and the Bacillus sp. FC1 lawn. Bacillus sp. FC1 cell suspension, previously exposed to glyphosate for $15 \mathrm{~h}$, was spread on a PDA plate with an incubated mycelial disc of Fusarium sp. The plates were incubated at $25^{\circ} \mathrm{C}$ in the dark, for two weeks. 
plates; whereas Fusarium sp. cultured in MMD and NB formed a clear zone surrounding the mycelium (Table 2 and Figure 6).

No evidence was found supporting any toxic secondary metabolites of Fusarium sp. over Bacillus sp. Therefore, it was assumed that the formation of halos on the plates was due to the disposition of the mycelial discs in the media, with Fusarium sp. previously competing for space and resources, thus excluding the bacterial cell growth (i.e., competitive exclusion) (Hardin 1960). Remarkably, an important aspect was revealed with the inversion of halos after two weeks of incubation. It is believed that the well-defined halos on the plates of treatments MMD and NB corresponded to the bacterium antagonistic action over the fungus (i.e., an inhibition halo) (Figures 6C and 6D). However, Fusarium sp. overlapped the halos on the plates in MMDH and NBH, what may indicate the sensitivity of the Bacillus sp. FC1 to the herbicide, supported by cell viability data (Figure 4), which initially affected its ability to compete with the phytopathogenic fungus.

Ahmad et al. (1995) also reported the influence of the bioherbicide phosphinothricin on interactions between phytopathogens and their antagonists, including B. subtilis, Pseudomonas flourescens and

Table 2. Halo occurrence in the treatments after glyphosate exposition.

\begin{tabular}{lcc}
\hline Treatments & 1st week incubation & 2nd week incubation \\
\hline MMD & $+/-$ & + \\
MMDH & + & - \\
NB & $+/-$ & + \\
NBH & + & - \\
\hline MMD: minimal medium dextrose; MMDH: minimal medium dextrose herbicide; \\
NB: nutrient broth; NBH: nutrient broth herbicide. (-) No halo; (+) strong halo; \\
$(+/-)$ moderate halo.
\end{tabular}

many Trichoderma species. According to their results, phosphinothricin has a strong impact on antagonistic bacteria, with $F$. oxysporum being able to expand over the entire plate area, when paired with either B. subtilis or P. fluorescens. The Bacillus species are also natural root-associated bacteria that can enhance plant growth by phosphate solubilization, ACC deaminase activity, production of siderophores and phytohormones (Souza et al. 2015). In this context, glyphosate could also have an adverse impact on functional traits, regarding plant growth.

The present study demonstrated that the Bacillus sp. FC1 decreases its population in response to glyphosate. These slow-growing bacteria tend to be less sensitive to glyphosate, resulting in an herbicide tolerance mechanism. Furthermore, there was also an experimental attempt to investigate the potential effect of the herbicide on the Bacillus sp. biocontrol, based on the antibiosis method against Fusarium sp. The hypothesis was that glyphosate could affect the biosynthesis of antifungal metabolites, considering the shikimate acid pathway disruption to be a precursor for a large number of secondary metabolites. Glyphosate did not show a marked inhibition of the Bacillus sp. FC1 antagonistic action over Fusarium sp. However, the sensitivity of the Bacillus sp. FC1 to the herbicide may affect its ability to compete with phytopathogenic fungi. These results provide insights into the interaction between herbicides and soil microorganisms, as well as perspectives for further studies to better understand how these compounds could affect bacterial functional traits.

\section{CONCLUSIONS}

1. Glyphosate affects the growth of the Bacillus sp. FC1 isolate;

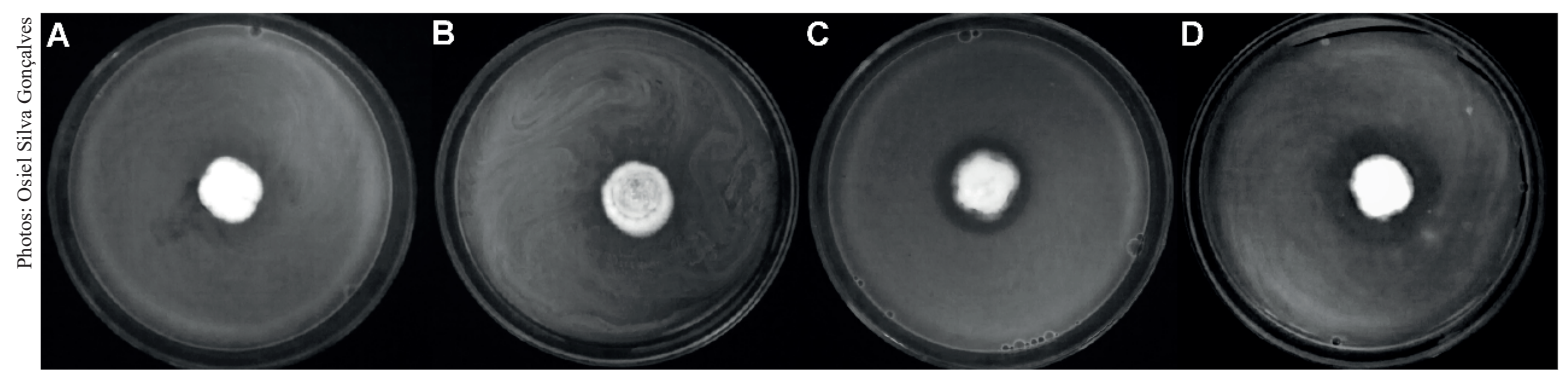

Figure 6. Antibiosis plates after two weeks of incubation evincing the inversion of halos with the Bacillus sp. FC1 in the following treatments: A) minimal medium dextrose herbicide; B) nutrient broth herbicide; C) minimal medium dextrose; D) nutrient broth. The results represent the data from the replicates $(n=3)$. 
2. No effect of glyphosate on the Bacillus sp. FC1 biocontrol activity was detected.

\section{REFERENCES}

AHMAD, I.; MALLOCH, D.; BISSETT, J. Influence of the bioherbicide phosphinothricin on interactions between phytopathogens and their antagonists. Canadian Journal of Botany, v. 73, n. 11, p. 1750-1760, 1995.

ARISTILDE, L.; REED, M. L.; WILKES, R. A.; YOUNGSTER, T.; KUKURUGYA, M. A.; KATZ, V.; SASAKI, C. R. S. Glyphosate-induced specific and widespread perturbations in the metabolome of soil Pseudomonas species. Frontiers in Environmental Science, v. 5, e34, 2017.

BRITO, R. L.; OLIVEIRA, R. de; ABE, F. R.; BRITO, L. B.; MOURA, D. S.; VALADARES, M. C.; GRISOLIA, C. K.; OliVEIRA, D. P. de; OliVEIRA, G. A. R. de. Ecotoxicological assessment of glyphosate-based herbicides: effects on different organisms. Environmental Toxicology and Chemistry, v. 36, n. 7, p. 1755-1763, 2017.

BUCHANAN, R. I.; GIBBONS, N. G. Bargey's manual of determinative bacteriology. 8. ed. Baltimore: Williams \& Wilkens, 1975.

DWORKIN, M.; FOSTER, J. W. Experiments with some microorganisms which utilize ethane and hydrogen. Journal of Bacteriology, v. 75, n. 5, p. 592-603, 1958.

EARL, A. M.; LOSICK, R.; KOLTER, R. Ecology and genomics of Bacillus subtilis. Trends in Microbiology, v. 16, n. 6, p. 269-275, 2008.

GILL, J. P. K.; SETHI, N.; MOHAN, A. Analysis of the glyphosate herbicide in water, soil and food using derivatising agents. Environmental Chemistry Letters, v. 15, n. 1, p. 85-100, 2017.

GRAY, D. A.; DUGAR, G.; GAMBA, P.; STRAHL, H.; JONKER, M. J.; HAMOEN, L. W. Extreme slow growth as alternative strategy to survive deep starvation in bacteria. Nature Communications, v. 10, n. 1, p. 890-902, 2019.

HARDIN, G. The competitive exclusion principle. Science, v. 131, n. 3409, p. 1292-1297, 1960.

HEUER, H.; KRSEK, M.; BAKER, P.; SMALLA, K.; WELLINGTON, E. M. Analysis of actinomycete communities by specific amplification of genes encoding 16S rRNA and gel-electrophoretic separation in denaturing gradients. Applied and Environmental Microbiology, v. 63, n. 8, p. 3233-3241, 1997.

KUMAR, M.; PHILIP, L. Enrichment and isolation of a mixed bacterial culture for complete mineralization of endosulfan. Journal of Environmental Science and Health, Part B, v. 41, n. 1, p. 81-96, 2006.
KUMAR, S.; STECHER, G.; TAMURA, K. MEGA7: molecular evolutionary genetics analysis version 7.0 for bigger datasets. Molecular Biology and Evolution, v. 33, n. 7, p. 1870-1874, 2016.

LANE, D. J.; PACE, B.; OLSEN, G. J.; STAHL, D. A.; SOGIN, M. L.; PACE, N. R. Rapid determination of $16 \mathrm{~S}$ ribosomal RNA sequences for phylogenetic analyses. Proceedings of the National Academy of Sciences of the United States of America, v. 82, n. 20, p. 6955-6959, 1985.

LOPES, R.; TSUI, S.; GONÇALVES, P. J. R. O.; QUEIROZ, M. V. A look into a multifunctional toolbox: endophytic Bacillus species provide broad and underexploited benefits for plants. World Journal of Microbiology and Biotechnology, v. 34, n. 94, p. 4-10, 2018.

MARTINS, P. F.; CARVALHO, G.; GRATÃO, P. L.; DOURADO, M. N.; PILEGGI, M.; ARAÚJO, W. L.; AZEVEDO, R. A. Effects of the herbicides acetochlor and metolachlor on antioxidant enzymes in soil bacteria. Process Biochemistry, v. 46, n. 5, p. 1186-1195, 2011.

NEWMAN, M. M.; HOILETT, N.; LORENZ, N.; DICK, R. P.; LILES, M. R.; RAMSIER, C.; KLOEPPER, J. W. Glyphosate effects on soil rhizosphere-associated bacterial communities. Science of the Total Environment, v. 543, n. 5, p. 155-160, 2016.

R CORE TEAM. $R$ : a language and environment for statistical computing. Vienna: R Foundation for Statistical Computing, 2017.

SCHULZ, A.; KRUPER, A.; AMRHEIN, N. Differential sensitivity of bacterial 5-enolpyruvylshikimate-3phosphate synthases to the herbicide glyphosate. FEMS Microbiology Letters, v. 28, n. 3, p. 297-301, 2006.

SHAFI, J.; TIAN, H.; JI, M. Bacillus species as versatile weapons for plant pathogens: a review. Biotechnology \& Biotechnological Equipment, v. 31, n. 3, p. 446-459, 2017.

SOUZA, R.; AMBROSINI, A.; PASSAGLIA, L. M. P. Plant growth-promoting bacteria as inoculants in agricultural soils. Genetics and Molecular Biology, v. 38, n. 4, p. 401-419, 2015.

TZIN, V.; GALILI, G. New insights into the shikimate and aromatic amino acids biosynthesis pathways in plants. Molecular Plant, v. 3, n. 6, p. 956-72, 2010.

VAN BRUGGEN, A. H. C.; HE, M. M.; SHIN, K.; MAI, V.; JEONG, K. C.; FINCKH, M. R.; MORRIS, J. G. Environmental and health effects of the herbicide glyphosate. Science of the Total Environment, v. 616-617, n. 1, p. 255-268, 2018.

VAN BRUGGEN, A. H. C.; SEMENOV, A. M. In search of biological indicators for soil health and disease suppression. Applied Soil Ecology, v. 15, n. 1, p. 13-24, 2000. 